\title{
Effect of sucrose on the fatty acid metabolism of adventitious root cultures in vitro of
}

\section{Stevia rebaudiana}

\author{
Efeito da sacarose no metabolismo dos ácidos graxos de culturas de raízes adventícias de Stevia \\ rebaudiana
}

Efecto de la sacarosa sobre el metabolismo de los ácidos grasos de cultivos de raíces adventicias de

\section{Stevia rebaudiana}

Received: 07/23/2021 | Reviewed: 07/29/2021 | Accept: 08/03/2021 | Published: 08/08/2021

\author{
Bruna Gabrieli Follador \\ ORCID: https://orcid.org/0000-0002-0835-9910 \\ State University of Maringa, Brazil \\ E-mail: brunafollador@gmail.com \\ Éverton da Silva Santos \\ ORCID: https://orcid.org/0000-0003-2400-2898 \\ State University of Maringa, Brazil \\ E-mail: everton.ds.santos@hotmail.com \\ José Eduardo Gonçalves \\ ORCID: https://orcid.org/0000-0002-2505-0536 \\ State University of Maringa, Brazil \\ E-mail: jose.goncalves@ unicesumar.edu.br \\ Regina Aparecida Correia Gonçalves \\ ORCID: https://orcid.org/0000-0003-4070-1269 \\ State University of Maringá, Brazil \\ E-mail: racgoncalves@uem.br \\ Arildo José Braz de Oliveira \\ ORCID: https://orcid.org/0000-0001-8737-0546 \\ State University of Maringá, Brazil \\ E-mail: ajboliveira@uem
}

\begin{abstract}
In this study, the effect of sucrose on the neutral lipid profile of adventitious root cultures of Stevia rebaudiana was evaluated. The cultures were obtained employing a roller bottle system. In this system, Schott-type flasks were used, which contained Murashige and Skoog liquid medium at 33.3\% strength (MS/3) supplemented with 30, 60, and $80 \mathrm{~g}$ $\mathrm{L}^{-1}$ of sucrose, respectively, and $10.7 \mathrm{mM} 1$-naphthaleneacetic acid (NAA). The spectroscopic analyzes showed that the portion of polyunsaturated fatty acids (PUFAs) was highest in roots treated with $30 \mathrm{~g} \mathrm{~L}^{-1}$ of sucrose. The spectrometric analyzes showed that the palmitic acid was found to be present in relatively higher amounts in the roots submitted to the MS/3-30 $\mathrm{g} \mathrm{L}^{-1}$ (31.9\%) and MS/3-60 $\mathrm{g} \mathrm{L}^{-1}(29.5 \%)$ sucrose treatments, and lower in the treatment with MS/3-80 $\mathrm{g} \mathrm{L}^{-1}(28.8 \%)$ of sucrose. Also, the treatment using $30 \mathrm{~g} \mathrm{~L}^{-1}$ of sucrose was the best for obtaining unsaturated fatty acids (UFAs) in the culture, with a relative percentage of $62.9 \%$. Our results indicate that the MS medium that received $30 \mathrm{~g} \mathrm{~L}^{-1}$ of sucrose induced a lesser abiotic stress condition, which favored PUFAs production in the adventitious root cultures of $S$. rebaudiana.
\end{abstract}

Keywords: Adventitious root cultures; Fatty acids; Stevia rebaudiana; Sucrose.

\section{Resumo}

Neste estudo, o efeito da sacarose no perfil lipídico neutro de culturas de raízes adventícias de Stevia rebaudiana foi avaliado. As culturas foram obtidas usando um sistema de garrafa giratória. Neste sistema, foram utilizados frascos do tipo Schott que continham meio líquido de Murashige e Skoog de 33,3\% de força (MS/3), suplementado com 30, 60 e $80 \mathrm{~g} \mathrm{~L}^{-1}$ de sacarose, respectivamente, e $10.7 \mathrm{mM}$ de ácido 1-naftalenoacético (ANA). As análises espectroscópicas dos extratos das raízes demonstraram que a porção de ácidos graxos poli-insaturados (AGPIs) foi mais alta nas raízes tratadas com $30 \mathrm{~g} \mathrm{~L}^{-1}$ de sacarose. As análises espectrométricas mostraram que o ácido palmítico estava presente em quantidades relativamente maiores nas raízes submetidas com tratamento de sacarose de MS/3-30 g L $\mathrm{L}^{-1}(31.9 \%) \mathrm{e}$ MS/3-60 $\mathrm{g} \mathrm{L}^{-1}$ (29.5\%), e em quantidades menores no tratamento de sacarose de MS/3-80 g L $\mathrm{L}^{-1}$ (28.8\%). No tratamento de sacarose de MS/3-80 $\mathrm{g} \mathrm{L}^{-1}$, o ácidos esteárico foi o ácido graxo prevalente (56.8\%). Além disso, o tratamento usando $30 \mathrm{~g} \mathrm{~L}^{-1}$ de sacarose foi o melhor para obtenção de ácidos graxos insaturados nas culturas com porcentagem relativa de $62,9 \%$. Nossos resultados indicaram que o meio MS que recebeu $30 \mathrm{~g} \mathrm{~L}^{-1}$ de sacarose induziu 
uma condição de menor estresse abiótico o que favoreceu a produção de AGPIs nas culturas de raízes adventícias de S. rebaudiana.

Palavras-chave: Ácidos graxos; Culturas de raízes adventícias; Sacarose; Stevia rebaudiana.

\section{Resumen}

En este estudio, se evaluó el efecto de la sacarosa sobre el perfil de lípidos neutros de cultivos de raíces adventicias de Stevia rebaudiana. Los cultivos se obtuvieron utilizando un sistema de botella giratoria. En este sistema se utilizaron matraces tipo Schott (con tapón), que contenían medio líquido Murashige y Skoog al 33,3\% de fuerza (MS/3) suplementado con 30, 60 y $80 \mathrm{~g} \mathrm{~L}^{-1}$ de sacarosa, respectivamente, y 10,7 mM ácido de 1-naftalenoacético (ANA). Los análisis espectroscópicos de los extractos de raíces mostraron que la porción de ácidos grasos poliinsaturados (AGP) fue mayor en las raíces tratadas con $30 \mathrm{~g} \mathrm{~L}^{-1}$ de sacarosa. Los análisis espectrométricos mostraron que el ácido palmítico estaba presente en cantidades relativamente mayores en las raíces sometidas a los tratamientos con sacarosa MS/3-30 g L L $^{-1}$ (31.9\%) y MS/3-60 g L-1 (29.5\%), y menor en el tratamiento con MS/3-80 g L-1 (28,8\%) de sacarosa. En el tratamiento con MS/3-80 $\mathrm{g} \mathrm{L}^{-1}$ de sacarosa, el ácido esteárico fue el ácido graso predominante (56,8\%). Además, el tratamiento con $30 \mathrm{~g} \mathrm{~L}^{-1}$ de sacarosa fue el mejor para la obtención de ácidos grasos insaturados (HUFA) en el cultivo, con un porcentaje relativo de 62,9\%. Nuestros resultados indicaron que el medio MS que recibió $30 \mathrm{~g}$ L-1 de sacarosa indujo una condición de menor estrés abiótico, lo que favoreció la producción de HUFAs en los cultivos de raíces adventicias de $S$. rebaudiana.

Palabras clave: Ácidos grasos; Cultivos de raíces adventicias; Sacarosa; Stevia rebaudiana.

\section{Introduction}

Stevia rebaudiana (Bertoni) Bertoni is a species of perennial shrub belonging to the family Asteracea (Asterales). This plant (in Guarani language Ka'ahe'ê) is native to South America (Tavarini, \& Angelini, 2013), and popularly known “sweet herb of Paraguay, sweet leaf, candy leaf, or honey leaf" (Soejarto, Kinghorn, \& Farnsworth, 1982; Brandle, \& Rosa, 1992; Madan et al., 2010).

S. rebaudiana is a species of nutritional importance, it has been applied industrially since the 1970s, during which Japanese researchers optimized techniques to extract glucoside steviosides (Dacome et al., 2005). The main producers of Stevia are China and Southeast Asian countries. Currently, this plant has been gaining importance since 2011 when steviol glucosides obtained from the leaves were recognized as a sweetener by some important regulatory agencies around the world (Tavarini, \& Angelini, 2013). In addition, recently, studies have shown that its roots are a rich source of inulin, a compound used as a prebiotic source (Lopes et al., 2016).

The use of plant tissue cultures and micropropagations in plant biotechnology are techniques that maintain the genetic stability of plants, which aim to produce primary and secondary metabolites for pharmacological and nutritional purposes (Wu et al., 2009; Thiyagarajan, \& Venkatachalam, 2012; Lopes et al., 2016).Thus, with the fast root growth that happens through in vitro procedures, it is possible to acquire sufficient raw material for the extraction and commercial production of bioactive metabolites without the destruction of natural biodiversity. The adventitious roots of $S$. rebaudiana represent an important and promising biotechnological alternative for obtaining bioactive substances, given their good propagation, conservation of the species can be achieved, as shown in our previous work using adventitious roots cultured in vitro (Reis et al., 2011; Lopes et al., 2016).

Some environmental stresses, such as temperature, sunlight, and variations in the composition of nutrients, can induce changes in the lipid composition of these root cells (Oksman-Caldentey et al., 1994; Singer, Zou, \& Weselake, 2016; Zhai et al., 2017). One reason is that neutral lipids(NLs), made up mainly of triacylclycerols (TAGs) and free fatty acids (FAs), provide not only energy and the building blocks for secondary metabolite biosynthesis by plants, but also play important roles in plant growth/survival when submitted to biotic and abiotic stresses. Thus, understanding all the physiological attributions of TAGs and FAs will be a crucial point for the future design of biotechnological strategies to overcome bottlenecks in increasing 
the production of metabolites of interest. Therefore, the present study aimed to evaluate the effect of sucrose concentration on the neutral lipid profile in the adventitious root cultures of $S$. rebaudiana by gas-liquid chromatography coupled to mass spectrometry (GC-MS) and nuclear resonance spectroscopy (NMR).

\section{Methodology}

The work corresponded to laboratory activities of semi-quantitative and qualitative character of the effect of sucrose on adventitious roots of Stevia rebaudiana cultured in vitro. The first one related to the establishment of the cultivation process of adventitious roots of $S$. rebaudiana. The second, in turn, is linked to the qualitative and quantitative assessment of the effect of different concentrations of sucrose on the pattern of neutral lipids and fatty acids. The research was carried out experimentally based on the procedures proposed by Jacomini et al. (2015) and using a comparative research method as described by Pereira et al. (2018), took into account the observation, recording and analysis of the objects of study and their relationship with other phenomena.

\subsection{Plant material}

Stevia rebaudiana (Bertoni) specimens were identified by Dr. Jimi Naoki Nakagima (Federal University of Uberlândia) in March 2008. An exsiccate was deposited at the Herbarium of the State University of Maringá, Brazil (14301HUEM). The seeds of S. rebaudiana were acquired from the Iguatemi Research Station of the State University of Maringá (FEI/UEM).

\subsection{Adventitious root cultures of Stevia rebaudiana}

Aseptic plants of S. rebaudiana were obtained according to the protocol of Reis et al. (2011). Root cultures of $S$. rebaudiana were then started from root tip explants about $1.5 \mathrm{~cm}$ long derived from in vitro rooting nodal explants on solid MS media supplemented with $10.7 \mathrm{mM}$ of 1-naphthaleneacetic acid (NAA) at $25 \pm 1{ }^{\circ} \mathrm{C}$, with 2 months of cultivation. The MS media (pH 5.8) was incorporated with $0.8 \%$ (w/v) agar. These cultures were successfully grown and maintained with regular subcultures every 4 weeks.

After 2 months of cultivation, roots were aseptically isolated from the explants, and the nutrient medium present was completely eliminated. Approximately $0.2 \mathrm{~g}$ of fresh roots were withdrawn and transferred to $500 \mathrm{~mL}$ Schott-type flasks containing $25 \mathrm{~mL}$ of MS liquid medium (pH 5.8), with 33.3\% strength (MS/3) that was supplemented, respectively, with 30, 60 and $80 \mathrm{~g} \mathrm{~L}^{-1}$ of D-sucrose and $10.7 \mathrm{mM} 1$-NAA. The adventitious roots of $S$. rebaudiana were cultivated in a roller bottle system at 2 rotations per minute (RPM) at $25 \pm 1^{\circ} \mathrm{C}$ under dark conditions. These roots were maintained under this culture condition for 15 days, after which they were transferred to $1 \mathrm{~L}$ Schott-type flasks containing $50 \mathrm{~mL}$ of MS/3 liquid medium that was supplemented, respectively, with 30,60 and $80 \mathrm{~g} \mathrm{~L}^{-1}$ D-sucrose and $10.7 \mathrm{mM}$ 1-NAA. The roots were then cultivated for another 30 days in the same conditions described above, as shown in Figure 1. 
Figure 1. Procedures of adventitious root cultures of Stevia rebaudiana trials.

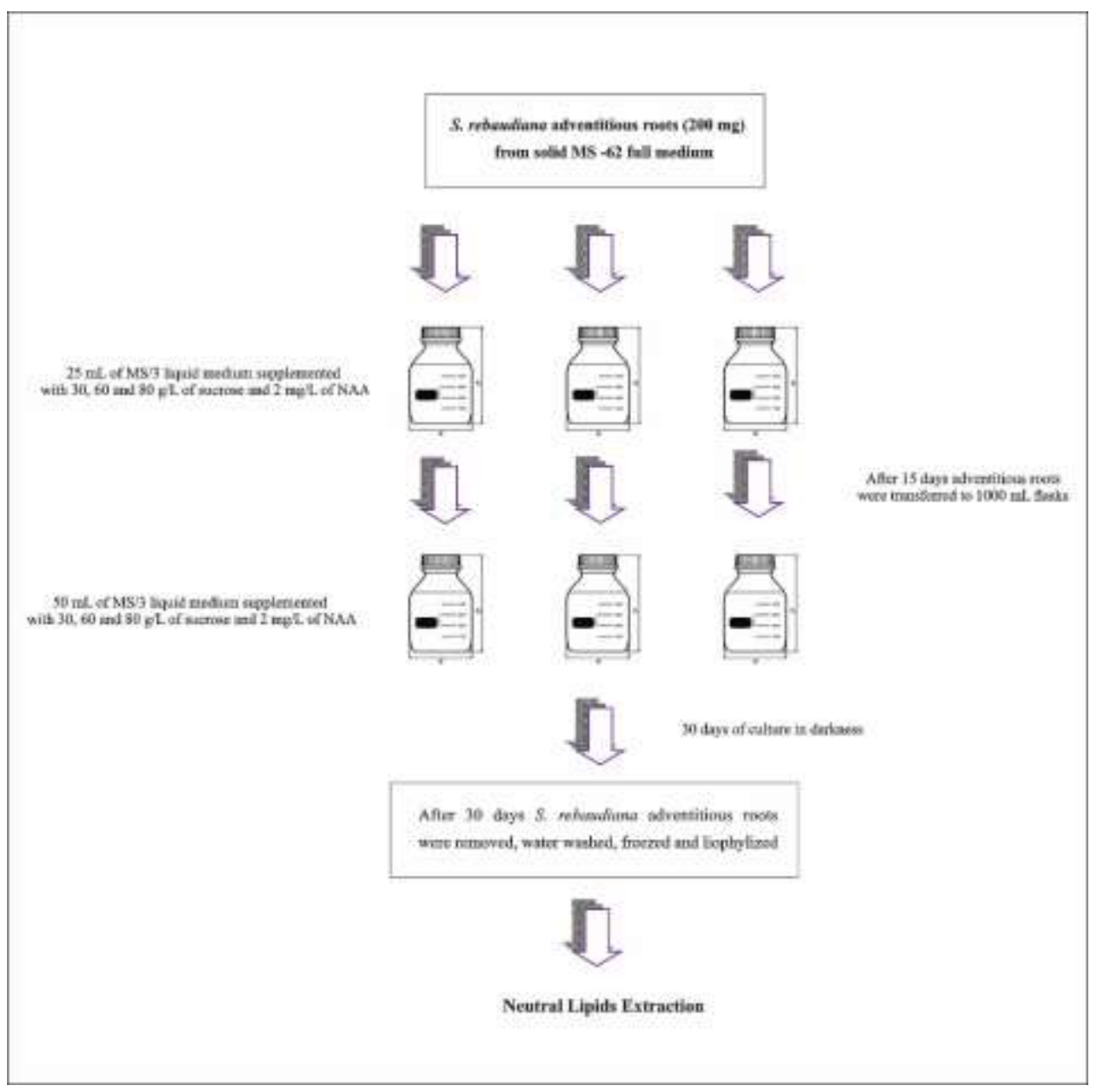

Source: Authors.

The Growth Index (GI) was determined by the dry weight of the root inoculated in the liquid MS medium and the final dry weight of the root obtained, after the lyophilization process (adapted from Sivanandhan et al., 2012), according to the equation described below, Eq. (1):

Growth Index $(\mathrm{GI})=\frac{\text { Dry root weight obtained }}{\text { Dry root of inoculated root }}(1)$

\subsection{Neutral lipids extraction}

The lyophilized adventitious roots obtained from the different treatments (SRR-30, SRR-60, and SRR-80) were extracted under reflux with hexane for $4 \mathrm{~h}$. After the extracts were filtered, the solvent was evaporated in a rotary evaporator $\left(35^{\circ} \mathrm{C}\right.$ ), yielding the crude extracts of neutral lipids (NLs). These samples were stored at $-20{ }^{\circ} \mathrm{C}$ until the respective analyzes.

\subsection{Neutral lipid analysis}

Fatty acids were chemically transformed into fatty acid methyl esters (FAMEs) by the transesterification of the NL samples (SRNL-30, SRNL-60, SRNL-80) with $1 \mathrm{~mL}$ of $1 \% \mathrm{NaOH}$ in $\mathrm{MeOH}$, with subsequent heating for $15 \mathrm{~min}$ at $55{ }^{\circ} \mathrm{C}$. Two milliliters of $5 \%$ methanolic $\mathrm{HCl}$ was then added, followed by heating for $15 \mathrm{~min}$ at $55{ }^{\circ} \mathrm{C}$ and the addition of $1 \mathrm{~mL} \mathrm{H}_{2} \mathrm{O}$ 
ultrapure. FAMEs were extracted with hexane $(3 \times 1 \mathrm{~mL})$ and evaporated to dryness in an evaporator. Samples were redissolved in $200 \mu \mathrm{L}$ hexane and stored at $-4{ }^{\circ} \mathrm{C}$ in glass vials until analysis by GC-MS (Kumari, Reddy, \& Jha, 2011).

\subsubsection{Gas-liquid chromatography coupled to mass spectrometry (GC-MS) analysis}

Gas-liquid chromatography coupled to mass spectrometry (GC-MS) analysis was carried out using a Gas Chromatography Agilent 7890B coupled with a Mass Spectrometer Agilent 5977A MSD and an HP5-MS UI-Agilent fused silica capillary $\left(30 \times 0.25 \mathrm{~mm} \times 0.25 \mathrm{~mm}\right.$; Agilent Technologies). The He was carrier gas used at a flow rate of $1 \mathrm{~mL} \mathrm{~min}^{-1}$. The temperature of the split injector (split ratio 1:30) was $250{ }^{\circ} \mathrm{C}$ and temperature of the transfer lines was maintained at 250 ${ }^{\circ} \mathrm{C}$. The operating specifications of the column were as follows: the initial temperature of the oven was $60{ }^{\circ} \mathrm{C}$ maintained for 4 $\min$, then 60 to $250^{\circ} \mathrm{C}$ at $10^{\circ} \mathrm{C} \mathrm{min}^{-1}$, and the final temperature was sustained for $28 \mathrm{~min}$. The mass spectrometer was operated in the electron impact mode, with electron energy of $70 \mathrm{eV}$ for the positive mode. Ionization source and quadrupole temperature were maintained at $230{ }^{\circ} \mathrm{C}$ and $150{ }^{\circ} \mathrm{C}$ respectively (Jacomini et al., 2015). The verification of the identity of the compounds was performed by checking their mass spectra with data from NIST 11.0 libraries (National Institute of Standards and Technology, US).

\subsubsection{Nuclear magnetic resonance spectroscopy (NMR)}

Nuclear magnetic resonance spectroscopy (NMR) spectra were recorded on a Bruker Avance HD III spectrometer operating at $500.13 \mathrm{MHz}$ for ${ }^{1} \mathrm{H}$ and $125.0 \mathrm{MHz}$ for ${ }^{13} \mathrm{C}$ nucleus. Samples of the NL crude extract (10 mg) were run in deuterated chloroform $\left(\mathrm{CDCl}_{3}\right.$; at $294.7 \mathrm{~K}$ ). The polyunsaturated fatty acid (PUFA) Eq. (2), saturated fatty acid (SFA) Eq. (4), and monounsaturated fatty acid (MUFA) Eq. (3), a content of S. rebaudiana adventitious roots was determined using spectra of ${ }^{1}$ H NMR (Figure 2 A), according to the methodology proposed by Usman et al. (2016).

$\mathrm{PUFA}=\frac{I_{z}}{I_{Y}}(2)$

Where: $\left(I_{Y}\right)$ integration of acyl group proton environment; $\left(I_{\mathrm{Z}}\right)$ integration of the bis-allylic proton environment.

$\operatorname{MUFA}=\left(\frac{I_{X}}{I_{2 Y}}\right)-$ PUFA (3)

Where: $\left(I_{2 \mathrm{Y}}\right)$ integration of acyl group proton environment; $\left(I_{\mathrm{X}}\right)$ integration of the allylic proton environment.

$\mathrm{SFA}=1-\left(\frac{I_{X}}{I_{2 Y}}\right)$

\subsection{Statistical analysis}

The results were presented as mean \pm standard deviation $(\mathrm{SD})$, followed by the statistical analysis employing the statistical software SISVAR version 5.3. ANOVA and Tukey's test $(p<0.05)$. 


\section{Results and Discussion}

\subsection{Effect of sucrose on the accumulation of biomass in adventitious root cultures in vitro of $S$. rebaudiana}

One of the main arguments to invest time and effort into the search for biotechnological alternatives for the production of bioactive metabolites is because the yields of these are normally low in the wild specimens, and often only found in specific plant tissues or species. However, natural production is rarely a viable option for the pharmaceutical and food industry. Therefore, several methodologies are being used to optimize the production of plant-derived metabolites, such as two-part culture systems, genetic engineering, and the use of bioreactor systems (Tocci et al., 2011; Georgiev, \& Weber, 2014; Wilson, Cummings, \& Roberts,2014; Simonetti et al., 2016). The elicitation technique, used to enhance the synthesis of metabolites in order to ensure plant survival, persistence or competitiveness, has proven to be a competent approach both in the ex vitro and in in vitro root systems (Tocci et al., 2012; Yin et al., 2012).

This bioreactor allows the flow of the culture medium to be uniform within the flasks, allowing the roots to properly absorb nutrients from the medium. This system was successfully used in the adventitious root cultures of $S$. rebaudiana by Reis et al. (2011) and Lopes et al. (2016).In this work, the effect of increasing concentrations of sucrose of $30 \mathrm{~g} \mathrm{~L}^{-1}, 60 \mathrm{~g} \mathrm{~L}^{-1}$ and $80 \mathrm{~g} \mathrm{~L}^{-1}$ onroot growth and the production of NLs in the adventitious root cultures of S. rebaudiana was evaluated.

The MS nutrient medium containing $30 \mathrm{~g} \mathrm{~L}^{-1}$ of sucrose resulted in the greatest root biomass, as the values of fresh weight (FW), dry weight (DW), and the growth index (GI) were better when compared to other sucrose treatments, as shown in Table 1.The lower root biomass in the treatments with 60 and $80 \mathrm{~g} \mathrm{~L}^{-1}$ of sucrose may be associated to the osmotic stress caused in the plant cell by the increased sucrose concentration. This osmotic effect could be causing an increase in the viscosity of the culture medium thus restricting the use of nutrients by the plant cells (Lee et al., 2006).The same observation of the osmotic effect of sucrose in adventitious root cultures was made by Cui et al. (2010) for Hypericum perforatum, Baque et al. (2012) for Morinda citrifolia and Wu et al. (2018) for Echinacea pallida and Echinacea purpurea, and also in cell cultures by Lee et al. (2006).

\subsection{Effect of sucrose stress on the neutral lipid composition of $S$. rebaudiana adventitious root cultures in vitro}

In this study, the yields of the hexane extracts, basically the neutral lipids (free FAs, TAGs, DAGs and MAGs), increased as the supply of sucrose in the nutrient medium increased, see Table 1. It was already expected that the increased supply of sucrose would increase levels of NLs, as the sugar conversion (ATP) obtained through photosynthesis is closely related to the production of FAs in plant cultures, providing basic carbon skeletons (Xu, \& Shanklin, 2016; Zhai et al., 2017).

Table 1. Growth in dry weight $(\mathrm{g} \pm \mathrm{SD})$, growth index (GI), and neutral lipid (NL) extract yield of adventitious roots after 30 days of cultivation in a bioreactor from $0.022 \mathrm{~g}$ of root biomass (dry weight), under different sucrose conditions.

\begin{tabular}{|c|c|c|c|}
\hline Treatment & Growth (g) & GI & NL yield (\%) \\
\hline $\mathrm{MS} / 3-30 \mathrm{~g} \mathrm{~L}^{-1}$ & $0.139 \pm 0.067$ & $6.317 \pm 3.084$ & 5.155 \\
\hline $\mathrm{MS} / 3-60 \mathrm{~g} \mathrm{~L}^{-1}$ & $0.203 \pm 0.040$ & $7.731 \pm 2.540$ & 6.671 \\
\hline $\mathrm{MS} / 3-80 \mathrm{~g} \mathrm{~L}^{-1}$ & $0.229 \pm 0.009$ & $10.423 \pm 0.417$ & 7.046 \\
\hline
\end{tabular}

* Statistically different by Tukey's test $p<0.05$. Source: Authors

However, our results demonstrate that the sucrose concentration of the culture medium did not significantly influence the production of FAs. Oksman-Caldentey et al. (1994) also demonstrated that FA production was not greatly affected by the increment of sucrose concentration in root cultures in vitro of Hyoscyamus muticus. 


\section{$3.3{ }^{1} \mathrm{H}$ and ${ }^{13} \mathrm{CNMR}$ neutral lipid analysis}

Through the analysis of ${ }^{1} \mathrm{H}$ NMR spectra of NLs from adventitious root cultures of $S$. rebaudiana, it was possible to detect the presence of FAs, TAGs, and DAGs, as shown in Figure 2 A, B, and Table 2. Table 3 shows the relative percentages of the PUFAs, MUFAs, and SFAs through the integration of the signals from the different proton environments. All signals were attributed by comparison with literature data (Thoss et al., 2012; Jacomini et al. 2015).

Figure 2A. ${ }^{1} \mathrm{H}$ NMR spectral profile of NL extracts of adventitious root cultures of Stevia rebaudiana in MS/3 medium supplemented with $2 \mathrm{mg} \mathrm{L}^{-1}$ of NAA and 30, $60 \mathrm{~g}$, and $80 \mathrm{~g} \mathrm{~L}^{-1}$ of sucrose. B. ${ }^{1} \mathrm{H}$ NMR spectral region between $5.60-1.80 \mathrm{ppm}$

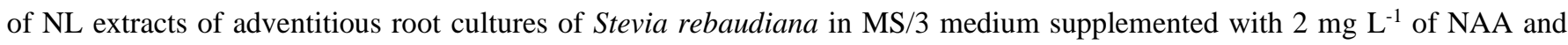
30,60 , and $80 \mathrm{~g} \mathrm{~L}^{-1}$ of sucrose.

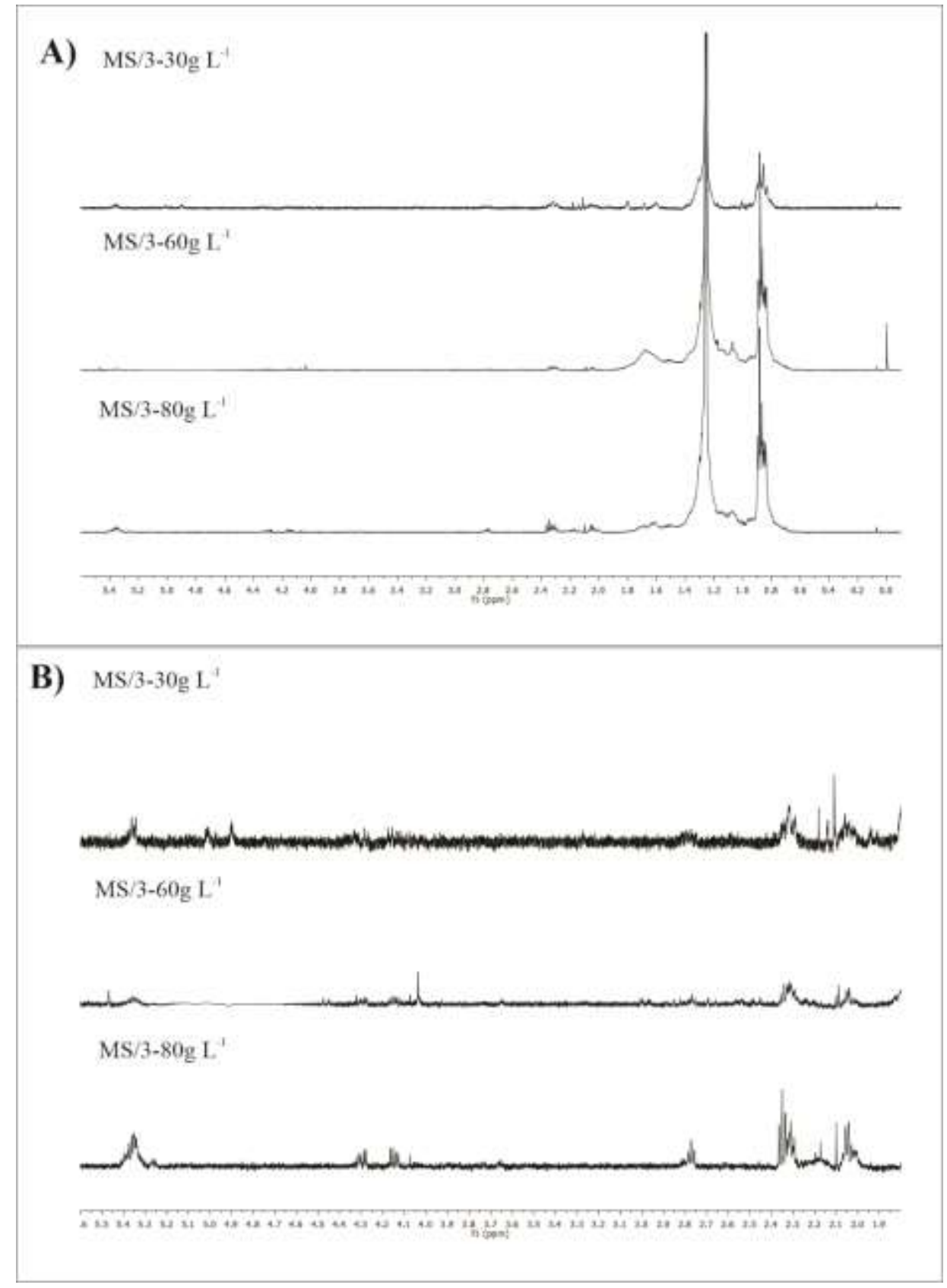

Source: Authors. 
Table 2. Chemical shifts and assignments of the characteristic resonance in the ${ }^{1} \mathrm{H}$ and ${ }^{13} \mathrm{C}$ NMR of NL extracts from adventitious root cultures of $S$. rebaudiana.

\begin{tabular}{|c|c|c|c|}
\hline \multirow[t]{2}{*}{ Position } & \multicolumn{3}{|l|}{${ }^{\delta} \mathrm{H}$} \\
\hline & NL $30 \mathrm{~g} \mathrm{~L}^{-1}$ sucrose & NL $60 \mathrm{~g} \mathrm{~L}^{-1}$ sucrose & NL $80 \mathrm{~g} \mathrm{~L}^{-1}$ sucrose \\
\hline Terminal methyl & 0.88 & 0.88 & 0.88 \\
\hline Methylene & 1.26 & 1.26 & 1.26 \\
\hline All acyl chains & 1.61 & 1.53 & 1.62 \\
\hline Allylics & 2.05 & 2.05 & 2.04 \\
\hline All acyl chains & 2.35 & 2.35 & 2.32 \\
\hline Bisallylics & 2.78 & 2.78 & 2.77 \\
\hline Glycerol (triglycerides) & $4.04-5.28$ & $3.75-5.26$ & $4.05-5.27$ \\
\hline Olefinic (all unsaturated chains) & 5.37 & 5.37 & 5.35 \\
\hline \multirow[t]{2}{*}{ Position } & \multicolumn{3}{|l|}{${ }^{\delta} \mathrm{C}$} \\
\hline & NL $30 \mathrm{~g} \mathrm{~L}^{-1}$ sucrose & NL $60 \mathrm{~g} \mathrm{~L}^{-1}$ sucrose & NL $80 \mathrm{~g} \mathrm{~L}^{-1}$ sucrose \\
\hline Terminal methyl & 14.1 & 14.1 & 14.1 \\
\hline Methylene & 29.7 & 29.7 & 29.7 \\
\hline All acyl chains & 22.7 & 22.7 & 22.6 \\
\hline Allylics & 27.0 & 27.0 & 27.2 \\
\hline All acyl chains & 31.9 & 31.9 & 31.9 \\
\hline Bisallylics & 24.4 & 24.4 & 24.4 \\
\hline Glycerol (triglycerides) & $62.1-68.8$ & 62.1 & $62.1-68.9$ \\
\hline Olefinic (all unsaturated chains) & $127.9-130.2$ & 130.2 & $127.9-130.0$ \\
\hline Carboxyl & 177.1 & 169.2 & 173.1 \\
\hline
\end{tabular}

Source: Authors.

In addition to the ${ }^{1} \mathrm{H}$ NMR spectrum, the ${ }^{13} \mathrm{C}$ NMR spectra were also obtained, as shown in the Figure $2 \mathrm{~B}$ and Tablr 2, further confirming the presence of NLs in the extracts. The chemical shifts to the triacylglycerides carbon atoms of NLs from S. rebaudiana adventitious roots were similar to literature data described for NLs from other plants (Thoss et al., 2012; Jacomini et al., 2015).

After the spectroscopic analysis, it was determined that SFAs predominate in all extracts regardless of the sucrose concentration to which the roots were submitted. Furthermore, the fraction of PUFAs was higher in roots treated with $30 \mathrm{~g} \mathrm{~L}^{-1}$ of sucrose and lower in roots treated with $60 \mathrm{~g} \mathrm{~L}^{-1}$ of sucrose. The fraction of MUFAs was lower in roots treated with $60 \mathrm{~g} \mathrm{~L}^{-1}$ of sucrose than in the other treatments, Table 3.

Table 3. Relative percentage (\%) of polyunsaturated fatty acids (PUFAs), monounsaturated fatty acids (MUFAs) and saturated fatty acids (SFAs) obtained by ${ }^{1} \mathrm{H}$ NMR in the NLs extracts from adventitious root cultures of $S$. rebaudiana in different sucrose concentrations.

\begin{tabular}{llll}
\hline Treatment & PUFAs & MUFAs & SFAs \\
\hline $\mathrm{MS} / 330 \mathrm{~g} \mathrm{~L}^{-1}$ & 20.79 & 15.39 & 63.82 \\
$\mathrm{MS} / 360 \mathrm{~g} \mathrm{~L}^{-1}$ & 15.74 & 7.18 & 77.08 \\
$\mathrm{MS} / 380 \mathrm{~g} \mathrm{~L}^{-1}$ & 19.35 & 11.70 & 68.95 \\
\hline
\end{tabular}




\subsection{GC-MS analysis}

The FAME profile of S. rebaudiana adventitious root cultures was established by GC-MS analysis (Figure 3, Table 4). The peaks corresponding to the FAME content of the samples were compared and identified using the NIST library match software.

All mass spectra of FAMEs showed the peak at $m / z 74$ responsive to saturated FAMEs, monounsaturated FAMEs show a base peak at $m / z 55$ and polyunsaturated fatty acids was confirmed by the characteristic base peak at $m / z 67$ compared to literature data (Tariq et al., 2011; Gunawan et al., 2013).

GC-MS data analysis showed that SFAs were the major FAMEs in all extracts (Table 4), which palmitic acid was the main FA detected. Interestingly, the relative content of stearic acid, a SFA, increased significantly in the NL extract of roots grown in medium supplemented with $80 \mathrm{~g} \mathrm{~L}^{-1}$ of sucrose, with a relative percentage of $56.8 \%$, in contrast to those grown with the opposite treatments of $60 \mathrm{~g} \mathrm{~L}^{-1}(5.90 \%)$ and $30 \mathrm{~g} \mathrm{~L}^{-1}$ of sucrose $(5.10 \%)$. This means there was a gradual reduction in the relative concentration of UFAs with sucrose increase in the culture medium (Table 4).

The medium supplemented with $30 \mathrm{~g} \mathrm{~L}^{-1}$ of sucrose was the most favorable for UFA production in the roots when compared with the results of the other treatments, with a relative percentage of $62.9 \%$ as describe in the Table 4 .

The application of osmotic stress by an increment of sucrose concentration did not appear to possess a negative influence on the relative amount of PUFA production; however, the sucrose concentration did not have a cumulative boosting effect on PUFA production either.

Figure 3. FAME profiles obtained by GC/MS analysis from NL extracts of adventitious root cultures of Stevia rebaudiana in MS/3 medium supplemented with $2 \mathrm{mg} \mathrm{L}^{-1}$ of NAA and 30,60 , and $80 \mathrm{~g} \mathrm{~L}^{-1}$ of sucrose.

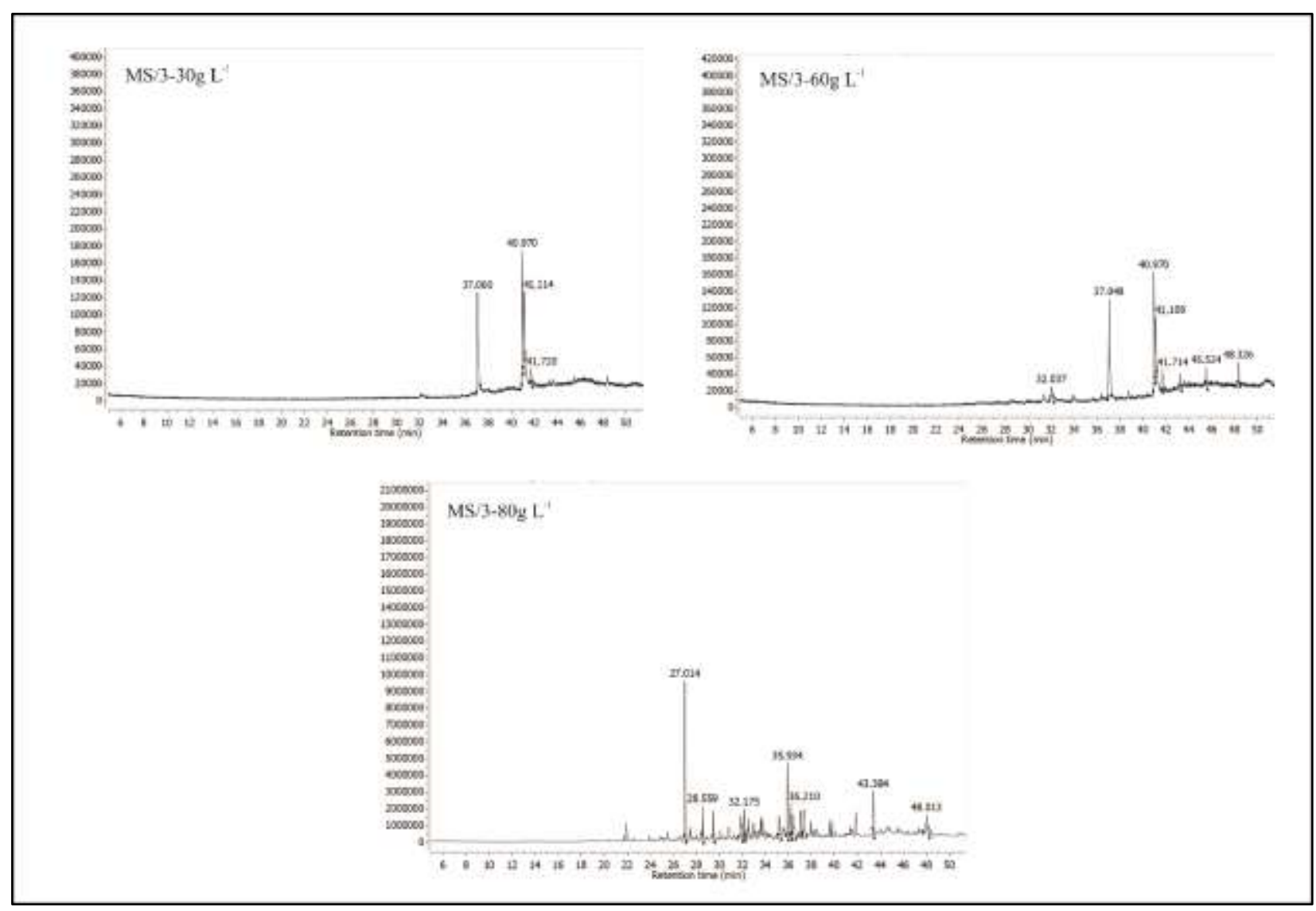

Source: Authors. 
TAGs in cytosolic lipid droplets are not only involved in membrane remodeling, but they also provide a source for the production of bioactive compounds derived from PUFAs involved in the plant defense mechanism. According to Shimada et al. (2014) and Shimada, Takano, \& Hara-Nishimura (2015) during fungal infections, leaf TAGs accumulate in lipid droplet types. These TAGs contain an abundance of PUFAs, which are consecutively arranged for the formation of oxylipins as defense compounds (Shimada, \& Hara-Nishimura, 2015). Equivalent to the chloroplast plastoglobules, the profusion of cytosolic lipid droplets also increases during adverse environmental conditions and senescence (Singer, Zou, \&Weselake, 2016). The amount of TAGs in the leaves appears to be linked to the stress tolerance of plants. Experiments that induced the suppression of TAG and FA degradation pathways, using mutant plants, resulted in an increment in leaf TAG content, but also caused necrosis and bleaching during dark and age-induced senescence (Slocombe et al., 2009). Together, this highlights the essentiality of TAG homeostasis in plant tissue.

Table 4. Relative percentage (\%) of FAMEs in the adventitious root cultures of $S$. rebaudiana under different sucrose concentrations determined by GC-MS.

\begin{tabular}{|c|c|c|c|c|}
\hline Fatty acid & MM & Group & $\mathrm{R}_{t}$ & RP \\
\hline \multicolumn{5}{|c|}{ NL $30 \mathrm{~g} \mathrm{~L}^{-1}$ sucrose } \\
\hline Palmitic & 256.43 & SFA & 37.1 & 31.9 \\
\hline Linoleic & 280.44 & PUFA & 40.9 & 26.7 \\
\hline Oleic & 282.47 & MUFA & 41.1 & 36.2 \\
\hline Stearic & 284.48 & SFA & 41.7 & 5.1 \\
\hline Total SFA & & & & 37.1 \\
\hline Total UFA & & & & 62.9 \\
\hline \multicolumn{5}{|c|}{ NL $60 \mathrm{~g} \mathrm{~L}^{-1}$ sucrose } \\
\hline Myristic & 228.20 & SFA & 32.0 & 7.7 \\
\hline Palmitic & 256.43 & SFA & 37.0 & 29.5 \\
\hline Linoleic & 280.44 & PUFA & 40.9 & 23.8 \\
\hline Oleic & 282.47 & MUFA & 41.1 & 30.8 \\
\hline Stearic & 284.48 & SFA & 41.7 & 5.9 \\
\hline Total SFA & & & & 43.1 \\
\hline Total UFA & & & & 54.6 \\
\hline \multicolumn{5}{|c|}{ NL $80 \mathrm{~g} \mathrm{~L}^{-1}$ sucrose } \\
\hline Palmitic & 256.43 & SFA & 37.1 & 28.8 \\
\hline Linoleic & 280.44 & PUFA & 40.9 & 11.5 \\
\hline Oleic & 282.47 & MUFA & 41.1 & 6.4 \\
\hline Stearic & 284.48 & SFA & 41.7 & 56.8 \\
\hline Total SFA & & & & 85.6 \\
\hline Total UFA & & & & 17.9 \\
\hline
\end{tabular}

MM: Monoisotopic molecular weight $\left(\mathrm{g} \mathrm{mol}^{-1}\right) ; \mathrm{R}_{t}$ : Retention time; RP: Relative Percentage. Source. Authors.

The effect of sucrose in the nutrient medium has been to increase the osmotic pressure causing oxidative stress in the plant cell with the formation of reactive oxygen species (ROS), such as hydrogen peroxide $\left(\mathrm{H}_{2} \mathrm{O}_{2}\right)$. ROS, in turn, cause lipid peroxidation of PUFAs with the formation of by-products such as malondialdehyde (MDA) (Baque et al., 2012 ; Cui et al. 2010). This phenomenon could be occurring in our study and would explain the reduction of PUFAs in the roots treated with a higher concentration of sucrose. Thus, to prove the oxidative stress described it would be interesting in future studies to evaluate the production of these compounds. In addition, changes in sucrose concentration also alter the production of secondary metabolites in plants, such as phenolic (Baque et al., 2012; Cui et al. 2010) and terpenoid compounds (Yin et al., 2013; Manuhara et al., 2015). Future perspectives of this work would be to evaluate the production of other groups of substances like phenolic and terpenoid compounds in the adventitious roots of S.rebaudiana, as well as their respective biological activities. 


\section{Conclusion}

The results of this work demonstrated that the MS/3 medium supplemented with $30 \mathrm{~g} \mathrm{~L}^{-1}$ of sucrose, for inducing a minor abiotic stress condition, is the more adequate for PUFA production/accumulation using the adventitious root cultures of S. rebaudiana.

Using this adventitious root culture methodology, new results can be achieved by studying the effects of different carbon sources on the production of polyunsaturated fatty acids as well as other primary and secondary metabolites. Abiotic stress conditions that can improve the results presented here will also be used.

\section{Acknowledgments}

The authors would like to thank Brazilian National Council for Scientific and Technological Development (CNPq, process $n^{\circ}$ 481915/2013-3) as well the Coordination for the Improvement of Higher Education Personnel and the Research Support Center Complex (CAMCAP) of the State University of Maringá.

\section{References}

Baque, M. A., Elgirban, A., Lee, E.-J., \& Paek, K.-Y. (2012). Sucrose regulated enhanced induction of anthraquinone, phenolics, flavonoids biosynthesis and activities of antioxidant enzymes in adventitious root suspension cultures of Morinda citrifolia (L.). Acta Physiologiae Plantarum.34: $405-415$. $10.1007 / \mathrm{s} 11738-011-0837-2$.

Brandle, J., \& Rosa, N. (1992). Heritability for yield, leaf: stem ratio and stevioside content estimated from a landrace cultivar of Stevia rebaudiana. Canadian Journal of Plant Science. 72(4): 1263-1266. 10.4141/cjps92-159.

Cui, X.-H., Chakrabarty, D., Lee, E.-J., \& Paek, K.-Y. (2010). Production of adventitious roots and secondary metabolites by Hypericum perforatum L. in a bioreactor.Bioresource Technology. 101(12): 4708-4716. 10.1016/j.biortech.2010.01.115.

Dacome, A. S., Silva, C. C., Costa, C. E., Fontana, J. D., Adelmann, J., \& Costa, S. C. (2005). Sweet diterpenic glycosides balance of a new cultivar of Stevia rebaudiana (Bert.) Bertoni: Isolation and quantitative distribution by chromatographic, spectroscopic, and electrophoretic methods. Process Biochemistry. 40(11):3587-3594. 10.1016/j.procbio.2005.03.035.

Georgiev, M. I., \& Weber, J. (2014). Bioreactors for plant cells: hardware configuration and internal environment optimization as tools for wider commercialization. Biotechnology Letters. 36(7): 1359-1367. 10.1007/s10529-014-1498-1.

Gunawan, S., Darmawan, R., Nanda, M., Setiawan, A. D., \& Fansuri, H. (2013). Proximate composition of Xylocarpus moluccensis seeds and their oils. Industrial Crops and Products.41: 107-112. 10.1016/j.indcrop.2012.04.010.

Jacomini, D., Sinzker, R. C., Mangolin, C. A., Grande, P. A., Nocchi, S. R., Nakamura, C. V., Oliveira, A. J. B., \&Gonçalves, R. A. C. (2015). Lipid profile and antiproliferative activity of callus cultures of Cereus peruvianus Mill. Industrial Crops and Products.69, 408-414. 10.1016/j.indcrop.2015.02.034.

Kumari, P., Reddy, C. R. K., \& Jha, B. (2011). Comparative evaluation and selection of a method for lipid and fatty acid extraction from macroalgae. Analytical Biochemistry. 415(2): 134-144. 10.1016/j.ab.2011.04.010.

Lee, E. J., Mobin, M., Hahn, E.J., Paek K. Y. (2006). Effects of sucrose, inoculum density, auxins, and aeration volume on ceil growth of GymnemasylvestreJournal of Plant Biology. 49(6): 427-431. 10.1007/BF03031122.

Lopes, S.M.S., Francisco, M.G., Higashi, B., Almeida, R.T.R., Krausová, G., Pilau, E.J., Gonçalves, J.E., Gonçalves, R.A.C., \& Oliveira, A.J.B. (2016). Chemical characterization and prebiotic activity of fructo-oligosaccharides from Stevia rebaudiana (Bertoni) roots and in vitro adventitious root cultures. Carbohydrate Polymers. 152: 718-725. 10.1016/j.carbpol.2016.07.043.

Madan, S., Ahmad, S., Singh, G., Kohli, K., Kumar, Y., Singh, R., \&Garg, M. (2010). Stevia rebaudiana (Bert.) Bertoni-a review. Indian.Journal of Natural Products and Resources. 1(3): 267-286.

Manuhara, Y. S. W., Kristanti, A. N., Utami, E. S. W., \& Yachya, A. (2015). Effect of sucrose and potassium nitrate on biomass and saponin content of Talinum paniculatum Gaertn. hairy root in balloon-type bubble bioreactor. Asian Pacific Journal of Tropical Biomedicine. 5(12): 1027-1032. 10.1016/j.apjtb.2015.09.009.

Murashige, T., \& Skoog, F. (1962). A revised medium for rapid growth and bio assays with tobacco tissue cultures. Plant Physiology. 15(3): 473-497. 10.1111/j.1399-3054.1962.tb08052.x.

Oksman-Caldentey, K.-M., Sevón, N., Vanhala, L., \& Hiltunen, R. (1994). Effect of nitrogen and sucrose on the primary and secondary metabolism of transformed root cultures of Hyoscyamus muticus. Plant Cell, Tissue and Organ Culture. 38: 263-272. 10.1007/BF00033886.

Pereira, A. S. Metodologia da pesquisa científica. UFSM, 2018. https://repos itorio.ufsm.br/bitstr eam/handle/1/15824/Lic_Computacao_MetodologiaPesquisa-Cientifica.pdf?sequence $=1$ 
Reis, R. V., Borges, A. P. P. L., Chierrito, T. P. C., Souto, E. R., Souza, L. M., Iacomini, M., Oliveira, A. J. B., \& Gonçalves, R. A. C. (2011). Establishment of adventitious root culture of Stevia rebaudiana Bertoni in a roller bottle system. Plant Cell, Tissue and Organ Culture. 106: 329-335. 10.1007/s11240-0119925-7.

Shimada, T. L., \&Hara-Nishimura, I. (2015). Leaf oil bodies are subcellular factories producing antifungal oxylipins. Current Opinion in Plant Biology. 25: 145-150. 10.1016/j.pbi.2015.05.019.

Shimada, T. L., Takano, Y., \& Hara-Nishimura, I. (2015). Oil body-mediated defense against fungi: from tissues to ecology. Plant Signaling \& Behavior. 10(2): e989036. 10.4161/15592324.2014.989036.

Shimada, T. L., Takano, Y., Shimada, T., Fujiwara, M., Fukao, Y., Mori, M., Okazaki, Y., Saito, K., Sasaki, R., \& Aoki, K. (2014). Leaf oil body functions as a subcellular factory for the production of a phytoalexin in Arabidopsis. Plant Physiology. 164(1): 105-118. 10.1104/pp.113.230185.

Simonetti, G., Tocci, N., Valletta, A., Brasili, E., D'Auria, F. D., Idoux, A., \& Pasqua, G. (2016). In vitro antifungal activity of extracts obtained from Hypericum perforatum adventitious roots cultured in a mist bioreactor against planktonic cells and biofilm of Malassezia furfur. Natural Product Research. 30(5): 544-550. 10.1080/14786419.2015.1028059.

Singer, S. D., Zou, J., \& Weselake, R. J. (2016). Abiotic factors influence plant storage lipid accumulation and composition. Plant Science. 243: 1-9. 10.1016/j.plantsci.2015.11.003.

Sivanandhan, D., Arun, M., Mayavan, S., Rajesh, M., Jeyaraj, M., Dev, G. K., Manickavasagam, M., Selvaraj, N., \& Ganapathi, A. (2012). Optimization of elicitation conditions with methyl jasmonate and salicylic acid to improve the productivity of withanolides in the adventitious root culture of Withania somnifera (L.) Dunal. Biotechnology and Applied Biochemistry. 168(3): 681-696. 10.1007/s12010-012-9809-2.

Slocombe, S. P., Cornah, J., Pinfield-Wells, H., Soady, K., Zhang, Q., Gilday, A., Dyer, J. M., \& Graham, I. A. (2009). Oil accumulation in leaves directed by modification of fatty acid breakdown and lipid synthesis pathways. Plant Biotechnology Journal. 7(7): 694-703. 10.1111/j.1467-7652.2009.00435.x.

Soejarto, D. D., Kinghorn, A. D., \& Farnsworth, N. R. (1982). Potential sweetening agents of plant origin. III. Organoleptic evaluation of Stevia leaf herbarium samples for sweetness. Journal of Natural Products. 45(5): 590-599. 10.1021/np50023a013.

Tariq, M., Ali, S., Ahmad, F., Ahmad, M., Zafar, M., Khalid, N., \& Khan, M. A. (2011). Identification, FT-IR, NMR ( ${ }^{1}$ H and ${ }^{13}$ C) and GC/MS studies of fatty acid methyl esters in biodiesel from rocket seed oil. Fuel Processing Technology. 92(3): 336-341. 10.1016/j.fuproc.2010.09.025.

Tavarini, S., \& Angelini, L. G. (2013). Stevia rebaudiana Bertoni as a source of bioactive compounds: the effect of harvest time, experimental site and crop age on steviol glycoside content and antioxidant properties. Science of Food and Agriculture. 93(9): 2121-2129. 10.1002/jsfa.6016.

Thiyagarajan, M., \& Venkatachalam, P. (2012). Large scale in vitro propagation of Stevia rebaudiana (Bert) for commercial application: Pharmaceutically important and antidiabetic medicinal herb. Industrial Crops and Products. 37(1): 111-117. 10.1016/j.indcrop.2011.10.037.

Thoss, V., Murphy, P. J., Marriott, R., \& Wilson, T. (2012). Triacylglycerol composition of British bluebell (Hyacinthoides non-scripta) seed oil. RSC Advances.12(2): 5314-5322. 10.1039/C2RA20090B.

Tocci, N., D'Auria, F. D., Simonetti, G., Panella, S., Palamara, A. T., \& Pasqua, G. (2012). A three step culture system to increase the xanthone production and antifungal activity of Hypericum perforatum subsp. angustifolium in vitro roots. Plant Physiology and Biochemistry.57: 54-58. 10.1016/j.plaphy.2012.04.014.

Tocci, N., Simonetti, G., D’Auria, F.D., Panella, S., Palamara, A. T., Valletta, A., \& Pasqua, G. (2011). Root cultures of Hypericum perforatum subsp. angustifolium elicited with chitosan and production of xanthone-rich extracts with antifungal activity. Applied Microbiology and Biotechnology. 91(4): 977987. $10.1007 / \mathrm{s} 00253-011-3303-6$.

Usman, A., Thoss, V., Darko, G., \& Itodo, A. U. (2016). Determination of triacylglycerol composition of Trichilia emetica seed oil using GC-MS and ${ }^{1} \mathrm{H}$ NMR spectroscopy. Advances in Analytical Chemistry. 6(1): 10-16. 10.5923/j.aac.20160601.02.

Wilson, S. A., Cummings, E. M., \& Roberts, S. C. (2014). Multi-scale engineering of plant cell cultures for promotion of specialized metabolism. Current Opinion in Biotechnology.29: 163-170. 10.1016/j.copbio.2014.07.001.

Wu, C., Popova, E. V., Hahn, E. J., \& Paek, K. Y. (2009). Linoleic and $\alpha$-linolenic fatty acids affect biomass and secondary metabolite production and nutritive properties of Panax ginseng adventitious roots cultured in bioreactors. Biochemical Engineering Journal. 47(1-3): 109-115. 10.1016/j.bej.2009.07.011.

Wu, C., Tang, J., Jin, Z., Wang, M., Liu, Z., Huang, T., \& Lian, M. (2018). Optimizing co-culture conditions of adventitious roots of Echinacea pallida and Echinacea purpúreain air-lift bioreactor systems. Biochemical Engineering Journal.132: 206-216. 10.1016/j.bej.2018.01.024.

Xu, C., \&Shanklin, J. (2016). Triacylglycerol metabolism, function, and accumulation in plant vegetative tissues. Annu.Rev. Plant Biology.67: 179-206. 10.1146/annurev-arplant-043015-111641.

Yin, H., Fretté, X. C., Christensen, L. P., \& Grevsen, K. (2012). Chitosan oligosaccharides promote the content of polyphenols in Greek oregano (Origanumvulgare ssp. hirtum). Journal of Agricultural and Food Chemistry. 60(1), 136-143. 10.1021/jf204376j.

Yin, S., Gao, W., Liang, Y., Wang, J., Liu, H., Wei, C., \& Zuo, B. (2013). Influence of sucrose concentration and phosphate source on biomass and metabolite accumulation in adventitious roots of Pseudostellaria heterophylla. Acta Physiologiae Plantarum. 35(5): 1579-1585. 10.1007/s11738-012-1199-0.

Zhai, Z., Liu, H., Xu, C., \& Shanklin, J. (2017). Sugar potentiation of fatty acid and triacylglycerol accumulation. Plant Physiology. 175(2): 696-707. 10.1104/pp.17.00828. 